\title{
Banking Employee Performance from Sulawesi - A Case Study
}

\author{
${ }^{1}$ Jefri Tamba and ${ }^{2}$ Renata Jillsy \\ ${ }^{1,2}$ Faculty of Management, Universitas Negeri Manado, Kabupaten Minahasa, Sulawesi Utara 95618, Indonesia \\ ${ }^{1}$ tamba43jefri@ hotmail.com
}

\begin{abstract}
Article Info
Journal of Journal of Enterprise and Business Intelligence (http://anapub.co.ke/journals/jebi/jebi.html)

Doi: https://doi.org/10.53759/5181/JEBI202101016

Received 05 March 2021; Revised form 31 March 2021; Accepted 25 April 2021.

Available online 05 July 2021.

(C2021 Published by AnaPub Publications.
\end{abstract}

\begin{abstract}
This study proposed to analyze and investigate the impact of strategic leadership and job design to improve work motivation and performance of employee in Bank BPD South Sulawesi and West Sulawesi. The analysis was performed using SEM analysis method with 130 respondents. This study suggested: strategic leadership and job design have a positive and significant direct impact on work motivation and performance, strategic leadership and job design have a positive and significant non-direct impact on performance mediated by work motivation.
\end{abstract}

Keywords - Strategic Leadership; Job Design; Work Motivation; Employee Performance.

\section{INTRODUCTION}

The national banking industry is facing a structural challenge, in line with the need for the digitization in the face of the digital age. This condition also ultimately encourage the efficiency and convenience, both for banks and customers [1]. Bank Sulsel is managed by the Regional Government-Owned Enterprise (BUMD) of the South Sulawesi Government. Its presence plays an important role in the process of managing regional finances. In the midst of the increasing challenges and competition in the banking industry, Bank Sulselbar has managed to achieve growth marked by an improvement in business and operational performance indicators over the past few years. The success of the directors and all levels of management and employees of Bank Sulselbar in utilizing economic conditions and developments over the last few years present important achievements that indicate the company's increasingly wellestablished position on the banking industry landscape in Indonesia.

Table 1: Mutation, Promotion and Demotion Bank Sulselbar 2018

\begin{tabular}{ll}
\hline Description & Total Employees \\
\hline Employee Mutation 2018 & 156 \\
Employee Promotion 2018 & 158 \\
Employee Demotion 2018 & - \\
Normal Retired (aged 55 yrs) & 15 \\
Respectfully Dismissed (Died) & 2 \\
Resignation at your own request & 9 \\
Direspectful dismissal & 3 \\
Unextended Contract & 1 \\
\hline
\end{tabular}

Based on the annual report of Bank Sulselbar recorded in 2018, Bank Sulselbar managed to record a net profit of IDR591 billion, growing by $9.64 \%$ compared to the previous year of IDR.539 billion. While the value of assets in 2018 was recorded at IDR 20,576 billion, an increase of 17.27\% compared to the previous year of IDR 17,546 billion. Bank Sulselbar's performance in 2018, in general, is also above the 2018 RBB.

The success of Bank Sulselbar in carrying out its business activities over the past few years is attributed to the support of adequate Human Resources (HR) to manage various organizational functions and face various challenges. Bank Sulselbar consistently and continuously strives to form and develop the potential of its human capital because the company views that qualified human resources are an important asset for the survival and success of the Bank of South 
Sulawesi in the future. Therefore, various initiatives have been carried out to maintain the quality of HR in Bank Sulselbar to suit business needs in an effective manner. We can see the process of mutation, rotation and demotion throughout 2018 in Table 1.

Based on the report above, it indicated that the number of promotions carried out by the company to employees was quite high. This motivates employees to work so that they can improve their efficiency and effectiveness at work. Likewise, the mutation process also showed a high number during 2018, but the problem was that many of the employees were not ready to be transferred both in terms of work environment and knowledge. Therefore, the duty of a leader is to be able to read the right conditions for subordinates to carry out the process of mutation, promotion and demotion. Leaders play a vital role in the sustainability of the organization in running its business.

There are two key elements in defining leadership: 1. convincing people on the principal issues and execution, and 2. providing a better platform for both individual and group to in achieving the collective goal. Leadership behavior can influence the employees, for example, their confidence, work satisfaction, performance, etc. It's understood that there is no perfect leadership model that will work universally for every situation or environment, so a situational/contingent approach in choosing the model of leadership that's effective is the best alternative.

Decision trade-offs are preferred in the work of strategic leader compared to other alternatives. Working hard, meticulously analyzing the condition, being a consistently and brutally honest, and asking the right question to the right individual at the right time are among the crucial traits all strategic leaders should possess. Imposing a reasonable and positive expectation on the performance of supervisor, peers, subordinates, and to themselves is crucial for strategic leaders to function in the company, thus strategic leadership is relevant at anywhere in the organizational hierarchy. In order to ensure the sustainability of strategic leadership in the organization, strategic leaders always enact a regeneration scheme to breed future leaders for the organization.

Bank Sulselbar has 24 branches in South Sulawesi and West Sulawesi with 1036 employees. It takes a leader who is able to direct employees to achieve company goals amid the intense competition between banks today. Research conducted by [2] suggested that leaders play an important role in improving work motivation and employee performance, so it is necessary to have communication and special attention to employee work motivation. Other research also found a significant influence of strategic leadership on employee performance.

Success in the business world, especially in the banking industry certainly requires good performance from employees, one way to keep the employee's performance better and to increase is to provide motivation to employees. Motivation is a psychological process that generates and directs behavior towards achieving goals [3]. In banking industry, employee motivation is very important because they engage directly with customers who are the company's target. As one of the banks that has many rivals, the Bank Sulselbar always gives freedom to every employee to innovate in dealing with customers, but the drawback is the weak supervision control given, because some employees still need income in doing work so that it becomes one of their motivations in work. Research conducted by [4] found that motivation contributed to the improvement of employee performance. Employees who are given the freedom to complete their work properly and are involved in various decision-making processes and setting organizational goals will improve their performance at work.

In addition to strategic leadership, another thing that influences work motivation and performance is good job design for employees. Motivating employees is one way for them to be able to work effectively and efficiently. Job design is something that must be considered in increasing employee motivation to progress the company. There are various approaches that allow management to design jobs for employee motivation, increased productivity, and future growth. Job design helps employees find their comfort zones at work so that it impacts on motivation and how they improve their performance. For job design to be effective, management needs to see what aspects of the work are important and more in line with organizational goals. Thus, one of the main objectives of job design is to be able to discuss what is needed from work and employees.

Bank Sulselbar's human resources are managed through the Human Resources Group whose function is to develop the potential and quality of human resources to become experts and excel in their fields. The HR Group always strives to provide manpower according to needs, both in terms of quantity and quality of HR expected to play a role in carrying out organizational functions to the full. And overall, Bank Sulselbar's HR Group is responsible for comprehensive HR management including recruitment, competency development, career management, and welfare improvement.

However, there are still some line improvements, especially related to the existing human resources at Sulselbar bank. One of the problems faced based on the 2018 annual report is as the responsibility of the president director is ensuring the fulfillment of professional HR and high integrity through management system policies and HR management strategies that are directed, transparent and comprehensive.

Previous research found that job design influences employee work motivation. Job design will provide the firmness and standard of work that must be achieved by each employee, job design must be clear so that employees are able to 
know their duties and responsibilities and the impact is that employee performance will improve. The study found a positive influence between job design and employee performance.

Based on the background stated above, the aim of this research is to study the influence of strategic leadership and job design on work motivation in improving the performance of Sulselbar BPD Bank employees in South and West Sulawesi

\section{Human Resources Management}

\section{LITERATURE REVIEW}

Effective and efficient utilization of human talent to achieve the goal of organization is the product expected from the system created by Human Resource (HR) management. Regardless of the scale of the company/organization, the scope of people's management should be view beyond the administration of employee payroll, employee training scheme or even the adherence to existing law. In order to maintain the relevance and the resilience amid the competitive market, the creative approach to HR management is crucial. In providing a rewarding work, it is critically important that all managers should seek to facilitate flexible and effective organization to productive and creative people. Hence, the idea of organization managing people become an important competency [5]. The scope of human resource management includes all activities related to human resources within the company, such activities include company design, employee formation, awarding, performance management, company employee development and external relations.

\section{Strategic Leadership}

In producing strategic change, it requires a capacity to anticipate, envision, maintain flexibility and empower people in order for the strategic leadership to function. Developing human resources and establishing a strategic direction, fostering an effective culture, utilizing core competencies, using effective organizational control system, and establishing ethical practices should be the focus in order to achieve an effective management of company's resources.

The analysis and contrast of different leadership styles has firmly cemented their position as the center of the focus for the past researches in the last three decades. Transactional and transformational style particularly captured the great interest from the scholars.

As a basis for measuring strategic leadership in organizations, six dimensions of strategic leadership are used, namely determining strategic direction, exploiting and maintaining key capabilities, developing human resources, supporting effective organizational culture, paying attention to ethical practices, and establishing strategic controls [6].

In an attempt to engender an ethical conduct in the organization, the approach utilized by strategic leaders is critical. Honesty, trust and integrity in the decision making and its implementation highlights the characteristic of the effective strategic leaders. Honesty, trust, and integrity take the moral high ground in the evaluation towards the actions taken by the organization. Hence, it is crucial for managers and employees in the structure of organization to have a strong faith on those values in order for them to comprehend the underlying principle behind all the course of action taken by the company or organization.

\section{Job Design}

Employee attitudes and behavior at work are affected by the job characteristics as suggested [7] further recommended that four "core" dimensions (i.e. variety, task identity, autonomy, feedback) used by Turner and Lawrence should be responded positively by the employees. The positive respond from the employee with a desire to improve its satisfaction at work to the core dimensions are expected as they have high propensity to see a worth in the opportunities and rewards that complex jobs offer.

Skill variety, task identity, task significance, autonomy and feedback are the key characteristics in the model established by [8]. The meaningfulness of work are contingent upon skill variety, task identity, and task significance; the sense of responsibility comes from autonomy; and outcome insight is accrued from feedback.

\section{Work Motivation}

Maslow specifically theorized that people have five types of needs and that these are activated in a hierarchical manner. This means that these needs are aroused in a specific order from lowest to highest, such that the lowest-order need must be fulfilled before the next order need is triggered and the process continues. If you look at this in a motivational point of view Maslow's theory says that a need can never be fully met, but a need that is almost fulfilled does not longer motivate. According to Maslow, it is crucial to acknowledge where a person is on the hierarchical pyramid in order to motivate him/her.

Robbins suggested that the it is crucial to identify and meet the need of people. The need of people can be categorized into deficiency needs (psychological, safety, social needs) and growth needs. Placed at the lowest at the triangle, dubbed as the most basic, is factors explanation physiological needs. Above higher is the safety needs and can 
function after the fulfillment of physiological needs. Upon the attainment of safety needs, the social needs surfaces, placed third in the hierarchy, and defined as the desire of acceptance and affection by other people. Esteem needs, placed higher than social needs, entails the need of self-respect and surrounding's approval. To recognize the commendable achievement, organization hosts an award banquet. Claiming the top at the tringle is the need of selfactualization. The success and prosperity of a business amid the dynamics and competitive environment is highly contingent upon the existence of motivation. Motivation encapsulates the internal characteristics of individual and external elements such as job factors, individual diversity and organizational conduct.

Astute execution is the key achievement in leadership and motivating employees can be done achieved through proper leadership. Motivation drives employee to have a good faith in the leadership and leaders thereby can assign the task of the company to be executed up to the company's expectation. Both leaders and employee shoulder an equal amount of responsibility to uphold high levels of moral conduct and motivation.

A study conducted in Pakistan indicated that employee motivation has positive relationship with organizational performance. This study specified the sample size of 150 employees of the different banks in Pakistan. For the analysis of the data used the multiple regressions in this study. All the different variables have the positive impact on employee's motivation. They contribute positively towards the employee's motivation.

\section{Employee Performance}

In the late 20th century, a great change in approaches to performance appraisal systems across the world was seen. There has been a great realization that it is more important to focus on defining, planning and managing performance than merely appraising performance. Despite the terminological difference, both performance appraisal and performance management share similar aim: assessing the performance of the employee. Nonetheless, it is suggested that performance management targets to achieve beyond assessing the performance.

The efficacy of the human resource management adopted by an organization heavily relies on how effective its performance appraisal and management system, hence performance appraisal is considered a very crucial element of HR management functionality. [9] divides performance into six dimensions: quality, quantity, timeliness, cost effectiveness, need for supervision and interpersonal impact.

\section{Conceptual Framework}

This conceptual framework illustrates the influence of strategic leadership and job design on work motivation in improving the performance of Bank Sulselbar BPD employees in South and West Sulawesi, as shown in figure 1.

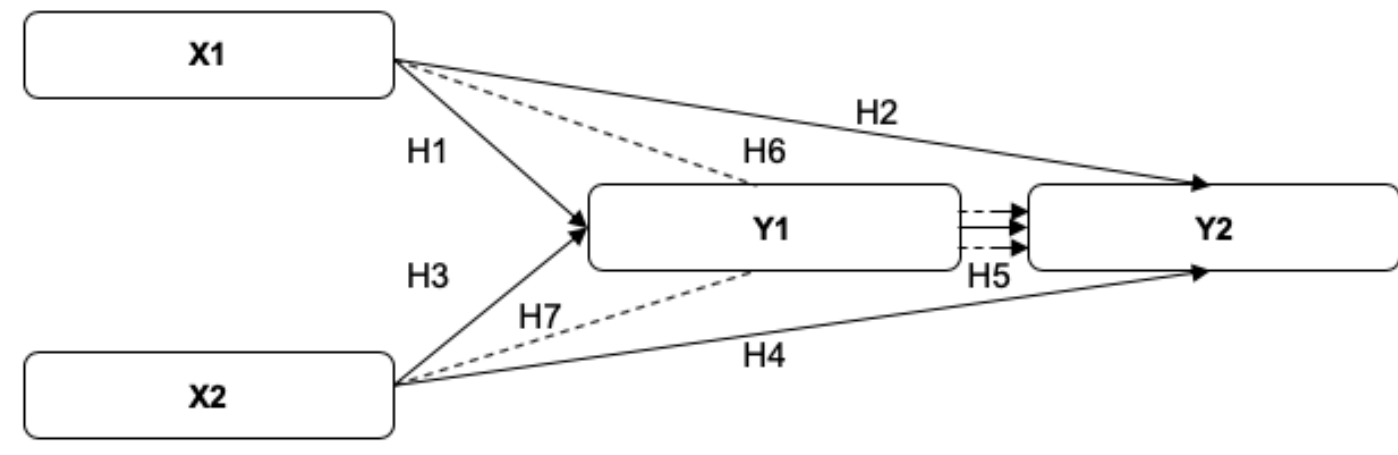

\section{Intervening Variabe}

Fig 1. Conceptual Framework

Notes:

$\mathrm{X} 1=$ Strategic Leadership

$\mathrm{X} 2 \quad=$ Job Design

Y1 = Work Motivation

Y2 = Performance

$\longrightarrow=$ Direct Effect

= Indirect Effect

H1 = Strategic Leadership has a positive and significant effect on work motivation 
$\mathrm{H} 2=$ Strategic Leadership has a positive and significant effect on performance

H3 = Job Design has a positive and significant effect on work motivation

H4 = Job Design has a positive and significant effect on performance

H5 = Work Motivation has a positive and significant effect on performance

H6 = Strategic Leadership has a positive and significant effect on performance through work motivation

H7 = Job Design has a positive and significant effect on performance through work motivation

\section{METHODOLOGY}

This research was conducted at the South Sulawesi and West Sulawesi South Sulawesi Regional Office with the number of respondents from the population of 1036 in 2018 then 100-200 samples were drawn [10]. The number of samples used as respondents was 130 consisting of 24 offices branches in South Sulawesi and West Sulawesi.

Data analysis techniques using SEM analysis and processed using smartPLS 2.0. Variables and indicators measured by using Likert Scale. Each item was measured using a five point likert scale, where value of $1=$ strongly disagree, $2=$ disagree, $3=$ neutral, $4=$ agree, and $5=$ strongly agree .

The study used four variables: strategic leadership and job design as independent variables, work motivation as an intervening variable and performance as the dependent variable. Strategic leadership variables are measured by indicators namely: strategic vision and mission, core competencies, human resource development, corporate culture, ethical practices, and strategic control. Job design variables use indicators of skills variation, job identity, task significance, work autonomy, and feedback [1]. Motivational variables are measured by several indicators: reward systems, security and safety, social sense, work rewards and self-actualization [2]. Performance variables are measured by a number of indicators: work quality, work quantity, timeliness, work effectiveness, independence, and interpersonal impact [2].

The data was collected directly by visiting the respondents in the field. Prior to this, field data, questionnaires as research instrument has to be valid and also reliable. Testing of questionnaires validity used Pearson Correlation coefficient test, whereas their reliability used Cronbach's Alpha test. Indicators of variables were considered as valid if its correlation value was greater than 0.30. Variables were considered as reliable if its Cronbach Alpha value was greater than 0.60 [3].

\section{RESULT AND DISCUSSION}

Before conducting the hypothesis test, the validity and reliability tests of each variable was carried out as shown in Table 2.

Table 2: Results of Validity and Reliablity Test

\begin{tabular}{ccccc}
\hline No & Variables/Indicators & $\begin{array}{c}\text { Correlation } \\
\text { Coefficient (r) }\end{array}$ & Cronbach's Alpha & Description \\
\hline $1 \quad$ Strategic Leadership (X1) & & 0.763 & Reliable \\
Strategic Vision and Mission & 0.705 & & Valid \\
Core Competency & 0.412 & & Valid \\
HRM Development & 0.721 & & Valid \\
Corporate Culture & 0.817 & & Valid \\
Ethical Practices & 0.826 & & Valid \\
Organizational Control & 0.537 & & Reliable \\
Job Design (X2) & & 0.736 & Valid \\
Skills Variation & 0.638 & & Valid \\
Job Identity & 0.490 & & Valid \\
Task Significance & 0.543 & & Valid \\
Work Autonomy & 0.866 & & Valid \\
Feedback & 0.859 & & Reliable \\
& Work Motivation (Y1) & & & Valid \\
& Reward System & 0.885 & 0.707 & Valid \\
& Security and Safety & 0.428 & & Valid \\
Social Sense & 0.743 & & Valid \\
& Work Rewards & 0.507 & Valid \\
& Self-Actualization & 0.762 & & Reliable \\
\hline
\end{tabular}




\begin{tabular}{ccc}
\hline Work Quality & 0.900 & Valid \\
Work Quantity & 0.835 & Valid \\
Timeliness & 0.666 & Valid \\
Work Effectiveness & 0.900 & Valid \\
Independence & 0.737 & Valid \\
\hline
\end{tabular}

The values of Cronbach's Alpha coefficient on all variables is more than 0.60. While, the above table shows the correlation coefficient value on each indicator is more than 0.30 . Therefore, it can be inferred that all indicators caused in the instrument or questionnaires are valid. Furthermore, this study used both descriptive statistic, and Structural Equation Modelling (SEM-PLS) as method of analysis. Then, data calculated by PLS2.0 Software.

Descriptive statistical analysis describes about the mean value of implementation research variables based on perception respondents. The complete results of respondent perceptions research variables are presented in Table 3 .

Table 3: The Mean Value of Variables

\begin{tabular}{|c|c|c|c|}
\hline No. & Variables & Indicators & Mean \\
\hline \multirow[t]{7}{*}{1} & \multirow{7}{*}{$\begin{array}{ll}\text { Strategic } & \text { Leadership } \\
(\mathrm{X} 1) & \end{array}$} & & 3.90 \\
\hline & & Strategic Vision and Mission & 3.81 \\
\hline & & Core Competency & 4.41 \\
\hline & & HRM Development & 3.58 \\
\hline & & Corporate Culture & 3.61 \\
\hline & & Ethical Practices & 3.77 \\
\hline & & Organizational Control & 4.19 \\
\hline \multirow[t]{6}{*}{2} & \multirow[t]{6}{*}{ Job Design (X2) } & & 4.12 \\
\hline & & Skills Variation & 4.40 \\
\hline & & Job Identity & 4.44 \\
\hline & & Task Significance & 4.31 \\
\hline & & Work Autonomy & 3.67 \\
\hline & & Feedback & 3.73 \\
\hline \multirow[t]{6}{*}{3} & \multirow[t]{6}{*}{ Work Motivation (Y1) } & & 3.80 \\
\hline & & Reward System & 3.71 \\
\hline & & Security and Safety & 3.79 \\
\hline & & Social Sense & 3.66 \\
\hline & & Work Rewards & 4.27 \\
\hline & & Self-Actualization & 3.53 \\
\hline \multirow[t]{7}{*}{4} & \multirow{7}{*}{$\begin{array}{l}\text { Employee } \\
\text { (Y2) }\end{array}$} & & 3.67 \\
\hline & & Work Quality & 3.67 \\
\hline & & Work Quantity & 3.60 \\
\hline & & Timeliness & 3.65 \\
\hline & & Work Effectiveness & 3.67 \\
\hline & & Independence & 3.67 \\
\hline & & Interpersonal Impact & 3.71 \\
\hline
\end{tabular}

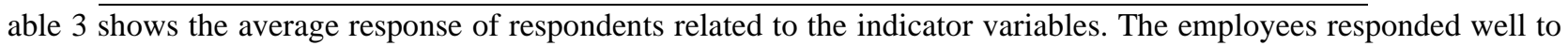
the indicators presented related to strategic leadership, job design, work motivation and employee performance. In the strategy variable leadership, the second indicator related to core competency has the highest value among other 
indicators, which is 4.41 , this indicates that the core competency has become the company's concern. On the competency variable, the job identity indicator has the highest response by the respondents with a value of 3.58 . On the motivation variable, the job appreciation indicator has the highest response among other indicators, which is 4.27. Performance variables with interpersonal impact indicators have the highest response among other indicators with a

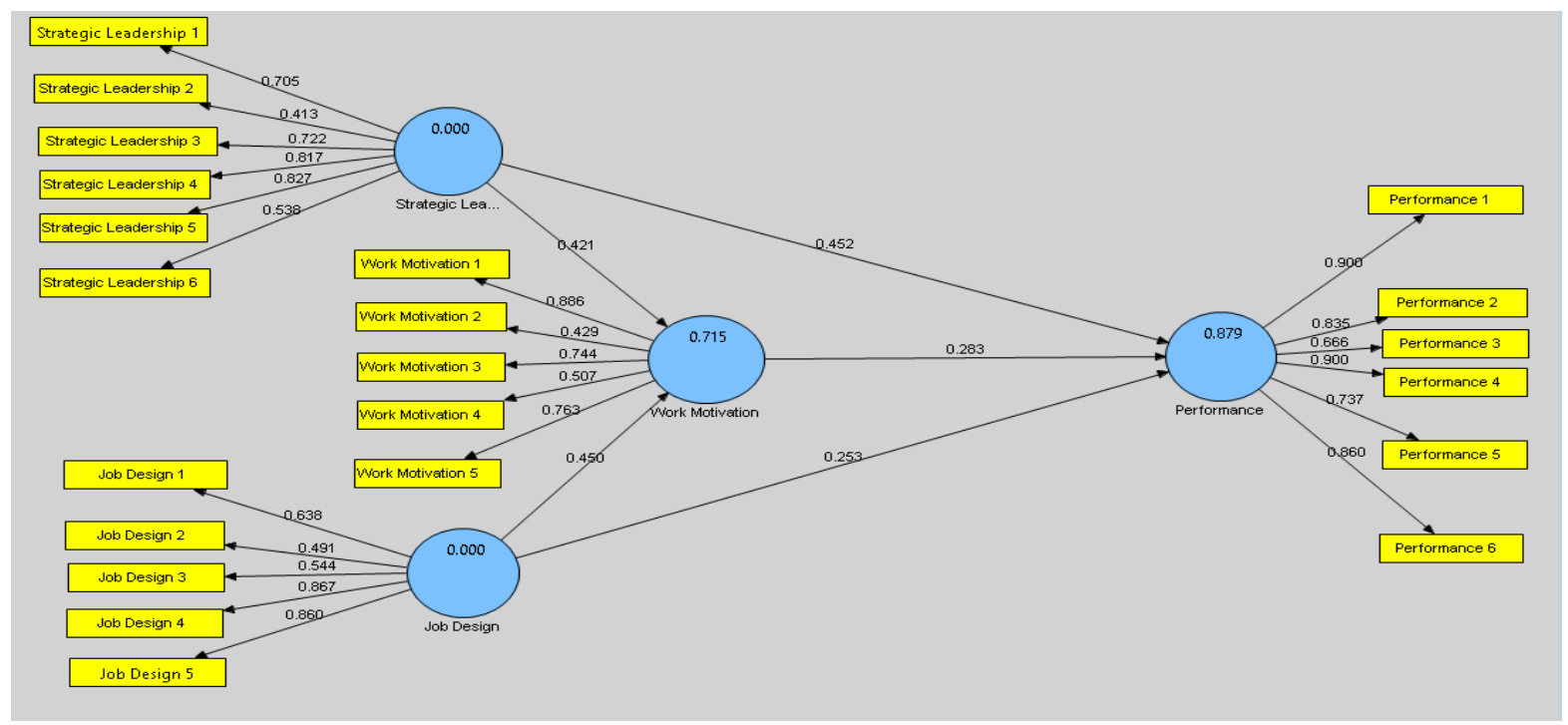

value of 3.71 , as shown in figure 2 .

Fig 2: Result of Empirical Model

Table 4: Results of Hypothesis Test

\begin{tabular}{|c|c|c|c|}
\hline & Paht Coefficient & T Statistics (|O/STERR $\mid)$ & Description \\
\hline $\begin{array}{ll}\text { Strategic Leadership } & -> \\
\text { Work Motivation } & \end{array}$ & 0.421 & 3.256 & Positive Significant \\
\hline $\begin{array}{l}\text { Strategic Leadership } \rightarrow> \\
\text { Performance }\end{array}$ & 0.452 & 5.100 & Positive Significant \\
\hline $\begin{array}{l}\text { Job Design }->\text { Work } \\
\text { Motivation }\end{array}$ & 0.450 & 3.296 & Positive Significant \\
\hline $\begin{array}{l}\text { Job Design } \quad \rightarrow \\
\text { Performance }\end{array}$ & 0.253 & 2.448 & Positive Significant \\
\hline $\begin{array}{l}\text { Work Motivation -> } \\
\text { Performance }\end{array}$ & 0.283 & 3.676 & Positive Significant \\
\hline Indirect Effect/Work motiv & as mediating Varia & & \\
\hline $\begin{array}{ll}\text { Strategic Leadership } & \text {-> } \\
\text { Work Motivation } & -> \\
\text { Performance } & \end{array}$ & 0.571 & 2.440 & Positive Significant \\
\hline $\begin{array}{lrr}\text { Job Design } & \rightarrow & \text { Work } \\
\text { Motivation } & & -> \\
\text { Performance } & & \end{array}$ & 0.380 & 2.459 & Positive Significant \\
\hline
\end{tabular}

Based on Table 4, the interpretation of each coefficient track was as follows:

Hypothesis 1: Strategic Leadership (X1) has a positive and significant impact on work motivation (Y1). A leader's main task is to maintain the sustainability of the organization and one that can be used is to motivate employees appropriately, give appropriate rewards to employees, create equal opportunities for employees to engage in organizational processes. claimed that the duty of a leader is to motivate employees so that employees are able to work well and utilize all the abilities of employees so they are able to develop in the organization. Sulselbar Bank has so far had many awards in various fields, this achievement is the pride of the company, employees feel their reputation improved by the company because of the hard work of employees who are part of the company's success so that this 
encourages them to remain motivated in work. This study is in line with past researches that suggested leadership has a positive and significant effect on employee work motivation .

Hypothesis 2: Strategic Leadership (X1) has a positive and significant impact on employee performance (Y2). Leaders can improve the performance of a team or organization by influencing the processes that determine the performance. An important objective in much of the leadership research has been to identify aspects of behavior that explain leader influence on the performance of a team, work unit, or organization. Strategic leadership sets organizational goals by building a strong vision and mission for the organization . The leadership in Sulselbar Bank has so far focused and explored the company's core competencies to improve employee performance. A leadership is trying to build a cooperation between employees emphasizing the effectiveness of employees in work as well as the quality of employee's work, so this encourages good performance of employees [9]. The similar studies also concluded that strategic leadership have a positive influence on employee performance.

Hypothesis 3: Job Design (X2) had a positive and significant impact on work motivation (Y1). Job design is something that must be considered in improving employee work motivation for company progress. Bank Sulselbar, in assigning tasks to its employees, is always in a clear manner and in accordance with work identities that are always related to each other, this makes employees feel comfortable at work because of the interrelation of work with each other. Organizations assign tasks by considering the conditions and abilities of employees, giving employees freedom to innovate so that they are motivated by the way they work. Researches conducted by [10] suggested that job design has a positive influence on employee work motivation. Employees who feel comfortable with their work will always be motivated at work therefore it is the crucial for the organization to make a complex work clear and there is feedback from subordinates to superiors and vice versa.

Hypothesis 4: Job Design (X2) had a positive and significant impact on employee performance (Y2). There are various approaches that allow management to design jobs for employee motivation, increased productivity, and future growth. For job design to be effective, management needs to see what aspects of the work are important and more in line with organizational goals. Thus, one of the main objectives of job design is to be able to discuss what is needed from work and employees. Bank Sulselbar prioritizes employee focus on work, the company makes work patterns so that employees are able to work together in completing work, this makes work between employees easier to complete so it has an impact on improving employee performance. The relevant research was conducted by [11] that suggested job design has a positive and significant effect on improving employee performance.

Hypothesis 5: work motivation (Y1) had a positive and significant impact on employee performance (Y2). Motivation is a psychological process that stimulates and directs behavior toward achieving goals [10]. Bank Sulselbar always rewards employees, especially those who exhibit good performance in the organization. Several types of awards are given by the company to employees, one of which the company gives to every employee to be involved in the decision-making process, so this makes employees feel valued for their performance. Similarly, there are awards for employees who have good performance they are given a reward for their work, so this always spur employees to improve their performance in the organization. This study is in line with some research, [12] found that motivation has an influence in improving employee performance [11], [12].

Hypothesis 6: Strategic Leadership (X1) had a positive and significant impact on employee performance (Y2) through work motivation (Y1). Strategic leadership is a form of leadership that uses the attributes of influence, motivation and communication but has the ability to establish the long-term direction of the organization while effectively establishing the day-to-day operational aspects. [1] states that the characteristics of strategic leadership is always encouraging the creation of changes in a positive and independent fashion, by itself allows others to be motivated to do the same thing and brave to take risks. Bank Sulselbar identifies, explores and focuses the main competencies of the company, so that employees feel helped by it. In addition, there is an award from the company so that trigger their motivation to work causes individual performance also increases. A Research recommended that strategic leaders exert influence by setting direction, motivation and communication so that employee performance increases.

Hypothesis 7: Job Design (X2) had a positive and significant impact on employee performance (Y2) through work motivation (Y1). Good job design can be an additional motivation for employees to achieve their work targets. An effective job design will make an employee perform a proper work, physically and emotionally, so as to increase their motivation in achieving organizational goals. Bank Sulselbar has given overall guidance in completing tasks by maintaining existing performance standards, when this is achieved there is a reward for what employees have achieved so as to motivate them to work towards organizational goals. Research conducted by [10] that there needs to be a good 
job design related to the work environment and other needs of an employee to increase their motivation to work so that it has an impact on employee performance.

\section{CONCLUSION}

In this study showed that strategic leadership and job design are very important to improve work motivation and employee performance in the company. The results showed a positive and significant influence of strategic leadership on work motivation and employee performance. Other variables in this study also showed a positive and significant effect of job design on work motivation and employee performance. This suggests the better strategic leadership contributes to the increasing work motivation which has an impact on increasing employee performance. Similarly, on job design, with a good job design for employees it improves their motivation to work which results in an increase in their performance.

\section{References}

[1]. A. Morrissey and J. Browne, "Waste management models and their application to sustainable waste management," Waste Management, vol. 24, no. 3, pp. 297-308, Jan. 2004.

[2]. G. M. Savage, "Basic hazardous waste management," Waste Management, vol. 23, no. 6, pp. 555-556, Jan. 2003.

[3]. A. Eicher, "Waste Management Introduction," Waste Management, vol. 22, no. 4, pp. 367-368, Jul. 2002.

[4]. L. F. Diaz, "Ethics in solid waste management," Waste Management, vol. 27, no. 5, pp. 593-594, Jan. 2007.

[5]. C. S. Poon, "Management of construction and demolition waste," Waste Management, vol. 27, no. 2, pp. 159-160, Jan. 2007.

[6]. L. F. Diaz, "Conferences on Solid Waste Management," Waste Management, vol. 26, no. 3, pp. 207-208, Jan. 2006.

[7]. M. Milke, "Guidelines for Waste Management reviewers," Waste Management, vol. 27, no. 6, pp. 727-728, Jan. 2007.

[8]. D. P. Komilis, "Issues on medical waste management research," Waste Management, vol. 48, pp. 1-2, Feb. 2016.

[9]. R. Cossu, "Waste and building materials: What type of articles should be submitted to Waste Management?," Waste Management, vol. 30, no. 5, pp. 735-736, May 2010.

[10]. E. Karakeçe, "The Core of Business: Is It Energy Management or Management Energy?," Contributions to Management Science, pp. 243-255, 2021.

[11]. D. Karamanis, "Management of moderate wind energy coastal resources," Energy Conversion and Management, vol. 52, no. 7, pp. 26232628, Jul. 2011.

[12]. A. P. Roskilly and M. Ahmad Al-Nimr, "Sustainable Thermal Energy Management," Energy Conversion and Management, vol. 159, pp. 396-397, Mar. 2018. 